\title{
The Professionalism of Accounting Teachers: Responding to the Rapid Change in the New Education Era
}

\author{
Dhika Maha Putri ${ }^{1,}$ Sunaryanto ${ }^{2,}$ Slamet Fauzan ${ }^{3 *}$ \\ 1,2,3 Faculty of Economy, State University of Malang \\ *Corresponding author. Email: slamet.fauzan.fe@um.ac.id
}

\begin{abstract}
The transition of the new era of education after the Covid-19 Pandemic from face to online has become a challenge in the world of education. This has an impact on how an educator is able to maximize the use of technology as teaching media. Educators must be able to adapt to various applications and technologies to maintain the quality of learning. Teachers are required to remain professional amid the dynamics of rapid change.

This study uses a qualitative approach with a case study method. This study examines the implementation of information and technology in accounting learning during the Covid-19 Pandemic. Through focus group discussions (FGD) and in-depth interviews with accounting educators in Malang City, it was concluded that many accounting educators have not yet utilized technology optimally in learning. The reason is the transition time from face-to-face learning to online learning is very limited. On the other hand, there are no guidelines and training related to technology implementation in accounting learning. Based on the description of the results, this study provides suggestions to design the training of trainers (TOT) curriculums for information and technology implementation in accounting learning.
\end{abstract}

Keywords: New Era Education, Rapid Change, Information and Technology, Teachers, Professionalism

\section{INTRODUCTION}

Since March 2020, Indonesia has been hit by a coronavirus pandemic which causes learning at all levels have to be carried out remotely to participate in breaking the chain of Covid-19 transmisssion (Bustomi, 2020). Distance learning is a challenge for education. This has an impact on how teachers are able to maximize technology as a teaching and learning aid. According to Bele and made (2018), educators must be able to master various applications and online learning platforms to maintain and improve the quality of learning. According to research carried out by Bustomi (2020), the implications of Covid-19 make faceto-face learning become online classroom learning. Online learning raises a variety of challenges ranging from different facilities and infrastructure, high internet costs, to the readiness of teachers and students in dealing with online learning (Bustomi, 2020; Herliandry \& Suban, 2020). The shift from face-to-face learning to online changes the role of the teacher into a coach and mentor. Digital technology has brought tremendous progress, based on the personal learning styles of each student (d'Orville, 2020). Therefore, teachers must be prepared with various conditions to always be able to do learning.

Teachers are required to be professional amid the dynamics of increasingly rapid change. If a teacher can be professional, it will help to improve the quality of education (Fadli, et. al, 2020). A teacher must have careful consideration of the connections and interactions within and outside the classroom which are required to develop teacher professionalism in improving teaching and learning outcomes (Lipscombe, et. al, 2020). The development of effective teacher professionalism is an ongoing challenge in the world of education. The emergence of synchronous and asynchronous technological innovations provides opportunities for teachers to develop their professionalism and skills outside the school's physical walls (Surette \& Johnson, 2015). According to May (2010), in the modern era, the role of teachers is changing, the teaching profession is increasingly becoming a reasonable career for common people, as long as they have high skills and professionalism. The importance of various competency training to achieve teacher qualifications as an educator in 
achieving learning objectives is necessary (Fritsch, et. al, 2015).

Moreover, in the world of accounting education, teachers are required to be professional in mastering accounting, both in theory and practice. Seeing technological progress with various demands on teachers regarding technology mastery, an educator is possible to be competent in order to obtain a set of skills, techniques, attitudes, and habits requiring the use of appropriate technological tools in learning (Hepp, et. al, 2015).

Students' academic achievement is one of the factors measuring teacher professionalism in learning. The process of transferring knowledge from teachers to their students is a benchmark for teachers' ability to provide material. In accounting, according to Helm (2015), there are significant overlaps and also specific dynamics in accounting data. First, unlike what is taught in mathematics and reading, accounting only focuses on the domain. Second, there is a strong emphasis on accounting practice and repetition. Therefore, the professionalism of teachers, especially accounting teachers is needed to support an effective learning both in theory and practice.

Teachers are the most important element in learning because thay are a benchmark of success in the process of transferring knowledge to students. A teacher must be able to master increasingly evolving technology (Fadli, et. al, 2020). One of the most profound changes in innovation is digital technology. The mastery of digital tools and processes is a guarantee of equality in education, which is a challenge for schools to create digital tools and applications that must involve teachers in digital competencies which are educational landmarks that cannot be avoided in the present and in the future (Hepp, et. al, 2015). According to Lipscombe, et. al (2020), teachers are encouraged to complete collaborative and collaborative tasks leading to transformative change directly related to learning. The collaborative system makes an extraordinary step towards defining, teaching and assessing skills. This will create an effective education program and have a positive impact on students (Ames, et. al, 2017). Every teacher is required to be able to master technology in the interests of a smooth learning process. If the teacher cannot adjust to technological changes, the authority of the teacher as a figure who is embraced and imitated will disappear, because students are more knowledgeable about technology than their teacher (Djaja, 2016).

According to Bele and Made (2018), teachers must master technology and information media skills to develop learning, one of which is ICT (Information and Communication Technology). The use of ICT in accounting learning has a purpose to improve students' abilities through a deep approach to learning. Students will strengthen their ability to connect what has been taught with workplace situations, this was stated by Tan and Wong (2020), in their research. In terms of the accounting market, employers assume that accounting students are prepared for their requirements and have a capable capacity to adapt a changing environment (Herrador-Alcaide, et. al, 2019). According to Boulianne (2016) and the report of the American Accounting Association (AAA), Information Technology (IT) must be included in the accounting learning curriculum. The addition of IT into accounting learning poses new challenges in development, teaching, renewal, and testing.

Particularly, emerging technologies are seen as the main platform for achieving innovative shipping and valuation methods. The new integrated learning environment is seen to provide distributed access to a seamless network of materials and relevant sources of information (Matthews \& Mcdonald, 2004). In accordance with research conducted by Tan and Wong (2020), in conducting learning using IT must be supported by the environment. The learning environment supported by IT will provide authentic learning experiences for students and therefore, it will encourage them to become quality students or prospective accountants.

According to Bobe and Cooper (2018), the use of technology for accounting learning adopts the 3P phase, which is the signaling phase, the process phase, and the production phase. This is done in order to determine student satisfaction in learning to account. A sign phase, containing the characteristics of students with the teaching process; the process phase contains the task approach (learning approach); and the production phase is the result of learning. From the research of Herrador-Alcaide, et. al, (2019), virtual learning spaces are generic and based on an open platform providing electronic tools for learning. In a virtual learning environment, there must also be a selfassessment tool because it is very important to enhance autonomous online learning and maximize opportunities and performance through training. D'Orville in his research stated that students in educational institutions are now in the $\mathrm{Z}$ generation. Generation $\mathrm{Z}$ students are accustomed to communicating with various social media platforms. In addition, they also see the power of working together to solve the world's great challenges, which not only involve Covid-19, but also the climate change crisis and mental 
health. Because the teacher is an alpha generation, the teacher is required to master the technology for learning (Herliandry \& Suban, 2020; D’Orville, 2020).

The Covid-19 Pandemic period demanded a rapid change from face-to-face learning to online. This certainly becomes a challenge for the teachers' proffesionalism. Learning in class is not only a matter of material, but also the use of media. Based on this, this study aims to narrate the use of Information and Communication Technology (ICT) in accounting online learning during the Covid-19 Pandemic.

\section{RESEARCH METHOD}

This research is a qualitative study using a narrative method. Narrative research can take the form of themes in a particular text or discourse in the form of inquiry in qualitative research (Chase, 2005). The results are a description of the teacher's experience in the online learning process during the Covid-19 pandemic. Narrative research according to Schreiber \& Asner-Self (2011) is the study of the lives of individuals as told through stories of their experiences, including discussions about the meaning of experiences for individuals. Types and sources of data used in this study include primary data and secondary data.

Primary data was processed from the results of online focus group discussion (FGD) studies with teachers related to the implementation of online learning during the Pandemic. The FGD was conducted online because this research was carried out during the Covid-19 Pandemic. Interviews were conducted with the teacher representatives who are members of the Malang City Accounting MGMP (accounting teachers association). The teacher selected as a resource is a teacher who teaches accounting subjects with an online system during the COVID 19 pandemic.

Secondary data in this study, are (a) government regulations regarding the learning process in schools at the Covid-19 Pandemic; (b) online learning content during the Covid-19 Pandemic; (c) online student learning outcomes at the time of the Covid-19 Pandemic; and (d) news related to the teaching and learning process at the Covid-19 Pandemic. Secondary research data obtained from the study of literature through search engines.

Data analysis in this study used an interactive model revealed by Miles and Huberman (1992). It is hoped that the model can narrate how evaluating online learning during the Covid-19 pandemic and the readiness of the campus and students to face new learning trends after the pandemic. The components of the interactive model, namely; (1) data collection; (2) data reduction; (3) data presentation; and (4) drawing conclusions.

\section{RESULTS AND DISCUSSION}

Permendiknas Number 16 of 2017 stated four compulsory competencies that must be mastered by teachers. These competencies are pedagogical competence, personality competence, professional competence, and social competence. others), implementation (the course of the learning process), and reflection (an overview of the time when the learning process occurs). Professional is a job or activity that is carried out by a person and becomes a source of income that requires expertise or skills that meet a certain quality or norms and require professional education (Kunandar, 2008).

This research is supported the result of the study conducted by Yusutria (2017), which states that teacher professionalism is reflected in the implementation of tasks characterized by expertise in both material and method. The professional character of the teacher is shown through the responsibility of carrying out all services. Professional teachers have social, intellectual, moral, and spiritual responsibilities. To improve teacher professionalism, teachers are required to carry out a more innovative learning process for students. Professional competences include the following, 1) mastering the structure and material of the curriculum in the field of study; 2) mastering the substance of the field of study and scientific methodology; 3) mastering and utilizing an information and communication technology in learning; 4) organizing curriculum materials for the field of study, and 5) improving the quality of learning through classroom action research.

Principally, it can be said that the main goal of education is, in general, the achievement of optimal future professional preparation. The existence of professional and competent teachers is a necessity to facilitate the achievement of learning objectives. A professional teacher will reflect the teacher's figure by having a broad insight and having a number of competencies that can support their duties. To become a professional teacher, teachers must have an authority over their quality and make their job as a work ethic (Karsidi, 2005). Professional teachers always strive to improve teacher quality and always update their competencies. Professional competence is related to mastery of the scientific structure of subjects nurtured extensively and deeply so that it can help teachers to guide 
students in mastering knowledge and skills optimally (Payong, 2011).

The COVID 19 pandemic has caused a very fast change in various aspects of life including education. This is a real test for the professionalism of a teacher. The use of ICT in online learning during COVID 19 made teachers have to learn a lot and adapt the teaching and learning process. Good mastery of technology becomes the fulcrum of a teacher's professionalism. Delivering material that can only be implemented online makes a teacher have to be active and creative in innovating learning media. Based on the results of the analysis in this study, it is known that there are several problems in learning accounting online during the COVID 19 Pandemic. These problems not only come from technicalities, but also caused by the lack of mastery of technology by teachers.

\subsection{Implementation of Online Learning during Covid- 19}

D'Orville (2020) stated that Covid-19 made the education system face a massive new crisis. According to UNESCO data in a study conducted by d'Orville (2020), 87\% students population in the world of around 1.5 billion students in 165 countries have been hampered by the learning process due to the temporary closure of educational institutions. Extended school closure not only eliminates learning in the short term, but also eliminates economic opportunities for adolescents in the education period. In addition to the impact on students, the COVID pandemic 19 also has an impact on how to teach a teacher at school. The transition from face-to-face learning to online is increasingly demanding high knowledge transfer capabilities from teacers. The use of digital technology in online learning makes teachers must be prepared with various conditions.

"However, we have to be prepared, like it or not, we must adapt to Covid's condition, rather than students can't study well" (N1)

"I admit it's difficult, sometimes it is exhausting. Learning technology and new habits is also not easy" (N2)

Accounting learning is one of the most complexes compared to learning other material, because accounting nature has more practice than theory. This has become a challenge for accounting teachers to package material so that it can be transferred well to students. Without reducing the quality of learning, teachers must strive so that students not only understand accounting theory but also master the practice. One of the learning media used by teachers when teaching accounting practices is face-to-face online (synchronous teaching)

"So far, if teaching journaling practices in accounting can only be through video conferencing. "(N2)

"To be honest, during the pandemic the practice of learning has stalled. Until now, we haven't found the right learning method yet (N1)

"My hope in this new normal learning, it's simple. I want to catch up on accounting practices. Hopefully, in the future there is the technology that can help practice learning "(N5)

The use of technology in online learning is carried out from upstream to downstream. The provision of material, task collection, and learning evaluation are all carried out by using the application and technology. In addition to accounting practices, teachers also provide assignments through Whatsapp and email applications.

"If we learn online, we use the Whatsapp group, and we will chat students by via Whatsapp" (N6)

"Actually I know, there are applications that can be used, a kind of virtual class. At that time, because the transition was fast and students had to keep learning, they are forced to not use them, because it takes time. (N2)

\section{"Usually it only uses Whatsapp and email" (N6)}

In addition to the limited understanding of technology experienced by teachers, there are other problems that make online learning more difficult. The ability of students, the internet network, and the support of authorized institutions become a challenge for teachers in undergoing online learning.

"Sometimes I want to force to use sophisticated technology and various things, but it can't, because my students are not able to follow "(N1)

"If the house is in a remote part of the mountain, I guarantee there is no signal. Normal telephone signals are difficult especially the internet" (N3)

"We need support from the authorities, when the policy is made there is an impact behind that. Including the matter of the internet network, the government should think about it" (N2)

"I think justice is necessary. If what is seen is only online learning in the city, it is indeed smooth. Please look again at the village, in the mountains, and in remote areas, the challenges are extraordinary ". (N4) 


\subsection{The use of Information and Communication Technology (ICT) by The Accounting Teachers}

Seeing technological progress with various demands on teachers regarding technology mastery, an educator is possible to be competent in order to obtain a set of skills, techniques, attitudes, and habits requiring the use of appropriate technological tools in learning (Hepp, et. al, 2015). Based on this, there are several expectations associated with increasing teacher professionalism in online learning, especially in the new learning era.

This expectation relates to the distribution of networks and also the provision of online learning training. Internet networks have become very much needed by teachers in online learning. Without adequate internet support, the teacher will not be optimal in transferring knowledge. This has become one of the things that can be sought by the government in the future. Cooperation between ministries and related institutions is needed so that the internet program into the village is really evenly distributed throughout Indonesia.

An adequate internet network is expected to encourage teachers to increasingly innovate in online learning. Innovation is needed primarily in learning to account. Nature accounting as a subject of many practices makes teachers must continue to carry out face-to-face online in order to oversee student progress. In addition, the use of innovative games and online quizzes must also be reproduced to improve students' critical attitude. In online learning, students must proceed independently, in order to improve their practical accounting abilities. Indeed, the transfer of knowledge via digital can be maximized if it is supported by adequate facilities and infrastructures.

"Good cooperation among government officials in order to support the children of the nation in online learning". (N4)

"Accounting needs practice, so I continue to face to face with students even though only through video calls. I did that so their practical abilities are maintained.

"I want to understand technology more deeply so that I can make interesting kinds of learning materials" (N3)

\subsection{Training of Information and Communication Technology (ICT) for Accounting Teacher}

As stated by Bele and Made (2018), a teacher must master the skills of technology and information media to develop learning, one of which is ICT (Information and Communication Technology). Teacher mastery of ICT is very much needed in terms of supporting the transfer of learning from teachers to students through online learning. In the world of accounting education certainly requires professional teachers who are able to master ICT technology to support the learning process. According to Pashev, et. al (2020), in determining learning objectives, dynamic training is necessary to achieve these goals. According to Hepp, et. al (2015), if we look at the new learning environment in terms of general transformation and teacher training related to the use of technology, there are three dimensions that need to be remembered. First, training programs must focus on the competencies needed by teachers in using technology for teaching purposes. Second, the emergence of new codes and languages from digital technology that brings new ways of thinking in accessing knowledge. Third, changing times are pushing to create teaching models that combine pedagogical innovation and open digital projects to foster creativity in the classroom.

"I think I need technology training, in order to be able to compile interesting teaching materials" (N5)

"I agree with the training. I want to use virtual classes not just chat with email only. (N1)

"If the teacher has been trained and smart in technology, of course, students will follow that ability. (N4)

One training model that can be used, is TOT (Training of Trainer). In a pandemic that changes rapidly, this model would be ideal because it functions like a snowball that has a streak. Training of Trainer (TOT) is training for trainers with the aim after following the training, they can be a coach for others. Various needs in online accounting learning ranging from manuals, textbooks to how to evaluate accounting learning both theory and practice are needed by an educators. TOT is able to explain the black box impact of teacher learning by incorporating transfer strategies. Transfer training is the application of knowledge and skills that have been learned to the work environment (Mcdonald, 2014).

According to research conducted by Weiss, et. al (2016) about the survey of transfer learning, explained that the 
transfer of learning used to improve students from one domain to a related domain. We can see examples from real-life non-technical ways to understand the transfer of learning. If there are two people who want to learn the piano. One person has no experience in playing music, but one other person has a background that can play the guitar and has extensive knowledge about music, person with extensive music experience backgrounds will be more effective and efficient by transferring their musical knowledge into the task of learning to play the piano. All of these theoretical points of view have provided some encouragement to promote understanding of TOT, practices, and platforms for future developments by using communication technology (ICT) in the future as stated by McDonald (2014). Training with TOT (Training of Trainer) models is expected to improve competencies, skills, attitudes, and habits in mastering the use of technology in learning.

\section{CONCLUSIONS}

This research presents an illustration of online learning during the Covid-19 Pandemic, especially in accounting subjects. The results showed that there are several challenges faced by teachers during online learning, including (1) the lack of students' technological abilities; (2) lack of internet network; (3) lack of support from authorized institutions; and (4) teacher understanding of technology. This challenge is increasingly felt given the nature of accounting which is a compulsory subject of practice. In line with this, in order to maintain the professionalism of teachers in dealing with rapid changes after the COVID-19 pandemic, there are a number of solutions that can be done, namely (1) increasing the means and infrastructure to support online learning; and (2) conducting training with TOT (Training of Trainer) models related to learning technology for teachers.

\section{REFERENCES}

[1]. Ames, A., Smith, K. L., Sanchez, E. R. H., Pyle, L., Ball, T., \& Hawk, W. J. (2017). Impact and persistence of ethical reasoning education on student learning: results from a module-based ethical reasoning educational program. International Journal Ethics and Education, 2(1), 77-96. doi: 10.1007/s40889-016-0031-x.

[2]. Bele, F., \& Made, D. (2018). Inovasi pembelajaran elektronik dan tantangan guru abad 21. Jurnal Penelitian dan Pengkajian Ilmu, 2(1), 10-18.

[3]. Bustomi, A. (2020). Implikasi covid-19 terhadap pembelajaran di perguruan tinggi. Jurnal
Tawadhu, 4(1), 1007-1017.

[4]. Bobe, B. J., \& Cooper, B. J. (2018). Accounting students' perceptions of effective teaching and approaches to learning: Impact on overall student satisfaction. Accounting and Finance, 60(3), 20992143. doi: 10.1111/acfi.12364.

[5]. Boulianne, E. (2016). How should information technology be covered in the accounting program? Canadian Journal of Administrative Science, 33(4), 304-317. doi: 10.1002/cjas.1405.

[6]. Djaja, S. (2016). Harapan dan tantangan guru pembelajar moda daring. Jurnal Ilmiah Ilmu Pendidikan, 10(2), 2548-7175.

[7]. D'Orville, H. (2020). COVID-19 causes unprecedented educational disruption: Is there a road towards a new normal? Prospects: Comparative Journal of Curriculum, Learning, and Assessment, 49, 11-15. doi: 10.1007/s11125020-09475-0.

[8]. Fadli, F., Astuti, S. I. D., \& Rukiyati, R. (2020). Techno-resilience for teachers: Concepts and action. TEM Journal, 9(2), 820-825. doi: 10.18421/TEM92-53.

[9]. Fritsch, S., Berger, S., Seifried, J., Bouley, F., Wuttke, E., Schnick-Vollmer, K., \& Schmitz, B. (2015). The impact of university teacher training on prospective teachers' CK and PCK - A comparison between Austria and Germany. Empirical Research in Vocational Education and Training, 7(1), 1-20. doi: 10.1186/s40461-0150014-8.

[10]. Helm, C. (2015). Determinants of competence development in accounting in upper secondary education. Empirical Research in Vocational Education and Training, 7(10). doi: 10.1186/s40461-015-0022-8.

[11]. Hepp, P. K., Prats Fernández, M. A., \& Holgado García, J. (2015). Teacher training: Technology helping to develop an innovative and reflective professional profile. RUSC. Universities and Knowledge Social Journal, 12(2), 30-43. doi: 10.7238/rusc.v12i2.2458.

[12]. Herliandry, L. D., \& Suban, M. E. (2020).Pembelajaran pada masa pandemi covid19. Jurnal Teknologi Pendidikan, 22(1), 65-70.

[13]. Herrador-Alcaide, T. C., Hernández-Solís, M., \& Sanguino Galván, R. (2019). Feelings of satisfaction in mature students of financial accounting in a virtual learning environment: an experience of measurement in higher education. International Journal of Education Technology, 16(1). doi: 10.1186/s41239-019-0148-z.

[14]. Karsidi, R. (2005). Profesionalisme guru dan peningkatan mutu pendidikan di era otonomi daerah. Seminar Nasional Pendidikan Dewan 
Pendidikan Kabupaten Wonogiri.

[15]. Kunandar. (2008). Guru profesional: Implementasi kurikulum tingkat satuan Pendidikan ( KTSP ) dan sukses dalam sertifikasi guru. Jakarta: Rajagrafindo Persada.

[16]. Lipscombe, K., Buckley-Walker, K., \& McNamara, P. (2020). Understanding collaborative teacher teams as open systems for professional development. Professional Development and Education, 46(3), 373-390. doi: 10.1080/19415257.2019.1613256.

[17]. Matthews, M., \& Mcdonald, A. (2004). Accounting education through an online-supported virtual learning environment. Active Learning in Higher Education, 5(2), 135-151. doi: 10.1177/1469787404043810.

[18]. McDonald, L. (2014). Transfer of the learning: Teacher professional development. European Journal of Social Behaviour and Science, 11(4), 1569-1584. doi:10.15405/ejsbs.140.

[19]. Pashev, G., Rusenova, L., Totkov, G., \& Gaftandzhieva, S. (2020). Adaptive workplace elearning model. TEM Journal, 9(2), 613-618. doi: 10.18421/TEM92-25.

[20]. Payong, M. R. (2011). Sertifikasi profesi guru (Konsep dasar, problematika dan implementasinya. Jakarta: PT Indeks.

[21]. Surrette, T. N., \& Johnson, C. C. (2015). Assessing the ability of an online environment to facilitate the critical features of teacher professional development. School Science and Mathematic, 115(6), 260-270. doi: $10.1111 / \mathrm{ssm} .12132$.

[22]. Tan, B. S., \& Wong, S. L. (2020). Learning principles of accounting in ICTsupported learning environments of Malaysian secondary schools: Future-oriented approach. Research and Practice in Technology Enhanced Learning, 15(11). doi: 10.1186/s41039-02000128-6.

[23]. Weiss, K., Khoshgoftaar, T. M., \& Wang, D. D. (2016). A survey of transfer learning. Journal of Big Data, 3(1). doi: 10.1186/s40537016-0043-6

[24]. Yusutria. (2017). Profesionalisme Guru Dalam Meningkatkan Kualitas Sumber Daya Manusia. Curiculla: Journal of Teaching and Learning, 2(1), 38-46. 